\title{
Insulin-Like Growth Factor-I Gene Analysis in Subjects with Constitutionally Variant Stature
}

\author{
HÉLĖNE SCHNEID, YVES LE BOUC, DANIELLE SEURIN, MICHELINE GOURMELEN, \\ SYLVIE CABROL, MARIE-CHARLES RAUX-DEMAY, FRANÇOIS GIRARD, AND \\ MICHEL BINOUX
}

Unité de Recherches sur la Régulation de la Croissance, INSERM U.142, and Laboratoire d'Explorations Endocriniennes, Hôpital Trousseau, 75012 Paris, France

\begin{abstract}
The IGF-I gene from leukocyte DNA of a control population of normal stature was studied using Southern blotting. Restriction fragment lengths for 21 enzymes were determined and three restriction fragment length polymorphisms (RFLP) were found (EcoRV, HindIII, and $P v u I I)$. In addition, the IGF-I gene of 64 constitutionally short subjects, five Pygmies, and 10 constitutionally tall subjects was analyzed. No IGF-I gene alterations were detectable by Southern blot in any of these conditions. Linkage analysis using genetic markers (RFLP) yielded results that were uninformative for five constitutionally short families investigated, owing to the limited number of RFLP and their low incidence (17\% for the 5.2kb HindIII, 5-kb PvuII RFLP alleles, and $13 \%$ for the 13kb $E c o$ RV RFLP allele). The EcoRV RFLP was found to map near Exon 1. The incidence of the 13-kb polymorphic allele with EcoRV proved to be lower (4\%) in the group with constitutionally short stature than in controls. These results could suggest that modifications in the region of the IGF-I gene may be involved in constitutionally short subjects. (Pediatr Res 27:488-491, 1990)
\end{abstract}

Abbreviations

$\mathrm{GH}$, growth hormone

RFLP, restriction fragment length polymorphism

The well-established role of IGF-I in postnatal growth is reflected clinically by variations in serum levels that are related to GH status in particular (1). Pygmies, who have normal GH secretion, exhibit a primary IGF-I deficiency (2). In children and adolescents with constitutionally variant stature, short subjects on average have lower, and tall subjects have higher levels of IGF-I than normals (3-6). Although these statural deviations represent etiologically heterogenous groups, the frequently familial nature of the deviations suggests that genetic alterations may be involved. We therefore set out to analyze the IGF-I gene using different restriction endonucleases, first in a control population, then in subjects with constitutionally variant stature and in Pygmies.

\section{MATERIALS AND METHODS}

Control subjects for gene analysis were French adults $(n=56)$ of normal stature (normal range $\pm 1 \mathrm{SD}$ ) (7). Subjects with

Received August 15, 1989, accepted December 15, 1989.

Correspondence: Hélène Schneid, INSERM U.142, Hôpital Trousseau, 26, Avenue du Docteur Arnold Netter, 75012 Paris, France.

Supported by the Institut National de la Santé et de la Recherche Médicale (INSERM), the Caisse Nationale d'Assurance Maladie des Travailleurs Salariés (CNAMTS), and the Contrat de Recherche Clinique de l'Assistance Publique (CRCAP). constitutionally variant stature were selected on the basis of criteria defined previously $(3,4)$. Sixty-four short subjects were studied (55 of whom were unrelated). Fifty-eight were children and adolescents, and six were fully grown. Ht was below $-2 \mathrm{SD}$ for the French population (7), the average being $-2.7 \mathrm{SD}$. Birth size was $49 \mathrm{~cm} \pm 1.2$ (mean $\pm \mathrm{SD}$ ). The mean body mass index (wt/ht ${ }^{2}$ ) was $15.8 \pm 1.6$, which is within the normal range. Five families were also investigated, comprising 24 subjects of whom 13 were constitutionally short. All short subjects had GH levels exceeding $14 \mathrm{ng} / \mathrm{mL}$ after ornithine infusion and the mean of the $\mathrm{GH}$ peaks $(22.7 \pm 7.3 \mathrm{ng} / \mathrm{mL}$, mean $\pm \mathrm{SD})$ was no different from that of normals (8). Ten constitutionally tall subjects (nine children and adolescents and one adult) were studied (ht above $+2 \mathrm{SD}$, the mean being $+3.4 \mathrm{SD}$ ). In all cases, wt was within the normal range (mean $\pm 1 \mathrm{SD}$ for ht). Thyroid hormone levels were normal in all subjects (free T4: $14.2 \pm 2.9 \mathrm{pg} / \mathrm{mL}$, TSH: $1.38 \pm 0.5 \mu \mathrm{U} / \mathrm{mL})$. Serum IGF levels were determined after separation by acidic gel filtration using methods reported earlier (9). IGF-I was measured by RIA and IGF-II by protein-binding assay using a cerebrospinal fluid binding protein with a selective affinity for IGF-II (10).

IGF-I levels were within the normal range (mean $\pm 2 \mathrm{SD}$ ) in the 58 constitutionally short children and adolescents, but twothirds of them (37 of 58) had values below the normal age mean (Fig. 1). Although there was no statistically significant difference between this group and controls, an earlier study covering a much larger number of subjects did reveal significantly lower levels (4). The mean value for the six fully-grown subjects was $378 \pm 79 \mathrm{ng} / \mathrm{mL}$ (mean $\pm \mathrm{SD}$ ), which is similar to that for normal adults $(300 \pm 56 \mathrm{ng} / \mathrm{mL})$. The constitutionally tall adult in this study had a normal IGF-I level $(326 \mathrm{ng} / \mathrm{mL})$. All but two of the tall children and adolescents, however, had IGF-I levels above the normal age mean (Fig. 1). Here, too, an earlier study on larger numbers of subjects had shown significantly higher IGF-I levels in constitutionally tall subjects than in controls (3, 6). IGF-II levels were normal in all subjects with constitutionally variant stature.

Samples were obtained from five adult Pygmies (four men and one woman) of the Aka tribe (Lobaye, Central African Republic). The mean ht of the men in the tribe was $154.2 \pm 6.3 \mathrm{~cm}$ (mean $\pm \mathrm{SD}$ ) and of the women, $144.2 \pm 6.4 \mathrm{~cm}$ (11). These ht are below -3 SD of the normal French population.

Preparation of genomic DNA. The procedure used was that of Miller et al. (12) with minor modifications. Leukocyte DNA was isolated from 10-20 mL blood (or buffy coats of nucleated cells) collected in anticoagulant (EDTA). Blood samples were stored at $-80^{\circ} \mathrm{C}$ until extraction of the DNA. Samples were rapidly thawed at $37^{\circ} \mathrm{C}$, washed twice with $40 \mathrm{~mL} 0.02 \mathrm{M}$ Tris- $\mathrm{HCl}$, pH 7.5, $0.005 \mathrm{M} \mathrm{MgCl}_{2}$. The lysed cells were resuspended in $3.5 \mathrm{~mL}$ $0.02 \mathrm{M}$ Tris- $\mathrm{HCl}, \mathrm{pH} 7.5,0.4 \mathrm{M} \mathrm{NaCl}, 0.002 \mathrm{M}$ EDTA and incubated for at least $4 \mathrm{~h}$ (or overnight) at $56^{\circ} \mathrm{C}$ with $0.2 \mathrm{~mL}$ $10 \% \mathrm{SDS}$ and $80 \mu \mathrm{L}$ proteinase $\mathrm{K}(10 \mathrm{mg} / \mathrm{mL})$. Proteins were 


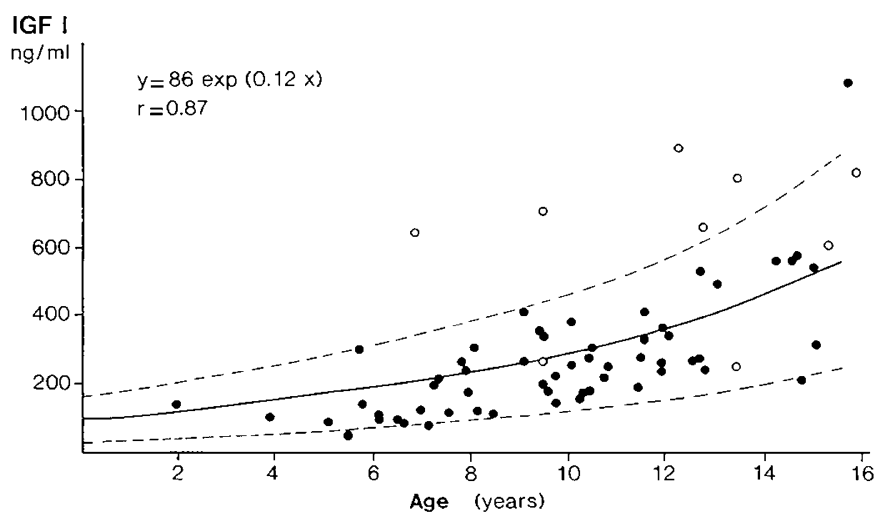

Fig. 1. Age-related variations in IGF-I levels during the growth period in constitutionally short $(O)$ and tall $(O)$ children and adolescents. The corresponding regression lines (mean $\pm 2 \mathrm{SD}$ ) for control children and adolescents have been reproduced for purposes of comparison.

precipitated by adding $1 \mathrm{~mL}$ saturated $\mathrm{NaCl}$, shaken vigorously, and centrifuged. Two vol of absolute ethanol were added to the supernatant at room temperature and the precipitated DNA strands removed with a pipette before being transferred to a microcentrifuge tube and resuspended in $0.2 \mathrm{~mL} 0.01 \mathrm{M}$ Tris$\mathrm{HCl}, \mathrm{pH} 7.5,0.001 \mathrm{M}$ EDTA.

DNA probes. The human liver IGF IA cDNA insert (1073 bp) from phage $\lambda$-TG03 (13) was subcloned in plasmid PGEM4 (pTG 3906). The 660-bp EcoRI-BamHI fragment, which contains the $5^{\prime}$-untranslated region, the coding region, and part of the $3^{\prime}$-untranslated region corresponding to the IGF IA mRNA (Exons 1, 2, 3, and 5) was used, as was the 152-bp 5'-EcoRIRsal fragment corresponding to Exon 1.

Southern blot analysis. Ten $\mu \mathrm{g}$ of purified leukocyte DNA were digested with 80 IU of restriction endonuclease as recommended by the manufacturers (Appligene, Illkirch, France, or New England Biolabs, Inc., Boston, MA) and the digested DNA submitted to electrophoresis in 0.7 to $1.2 \%$ agarose gels with $1 \mathrm{mg} / \mathrm{L}$ ethidium bromide. Thereafter the DNA was denatured and transferred to a nylon membrane (Gene Screen Plus, New England Nuclear, Boston, MA) according to the alkaline method (14). Transfer was carried out for $3 \mathrm{~h}$ using a solution of $0.4 \mathrm{M}$ $\mathrm{NaOH}, 0.6 \mathrm{M} \mathrm{NaCl}$ as transfer solution. The membrane was

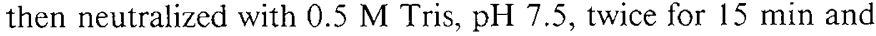
twice for $10 \mathrm{~min}$ with $2 \times \operatorname{SSPE}(1 \times \mathrm{SSPE}=0.01 \mathrm{M}$ phosphate buffer, $\mathrm{pH} 6.8,0.001 \mathrm{M}$ EDTA, $0.15 \mathrm{M} \mathrm{NaCl}$ ) and baked for 45 min at $80^{\circ} \mathrm{C}$.

Hybridization with IGF-specific probe was achieved as follows. First, the DNA blot was incubated for $2 \mathrm{~h}$ at $42^{\circ} \mathrm{C}$ with prehybridization buffer comprising $50 \%$ formamide, $5 \times \operatorname{SSC}(1 \times$ $\mathrm{SSC}=0.15 \mathrm{M} \mathrm{NaCl}, 0.015 \mathrm{M}$ sodium citrate, $\mathrm{pH} 7), 5 \times$ Denhardt's Solution $(1 \times$ Denhardt's $=0.02 \mathrm{~g} / \mathrm{L}$ Ficoll, $0.02 \mathrm{~g} /$ $\mathrm{L}$ polyvinyl-pyrrolidone, $0.02 \mathrm{~g} / \mathrm{L}$ BSA), $0.05 \mathrm{M}$ sodium phosphate buffer, pH $6.5,1 \% \mathrm{SDS}$, and $100 \mathrm{mg} / \mathrm{L}$ sonicated, denatured salmon sperm DNA. Then, hybridization was continued for $20 \mathrm{~h}$ at $42^{\circ} \mathrm{C}$ using the same buffer without the salmon sperm DNA and with $5 \%$ dextran sulphate and approximately $10^{7}$ $\mathrm{cpm} / \mathrm{mL}$ of the probe (sp act: $1-2 \times 10^{9} \mathrm{cpm} / \mu \mathrm{g}$ DNA). The 660 -bp probe was labeled with $\alpha{ }^{32} \mathrm{P}$ dATP (Amersham, Little Chalford, England) by random priming (kit, Amersham) according to the manufacturer's instructions. The blot was washed twice for $15 \mathrm{~min}$ at room temperature in a solution containing $2 \times \mathrm{SSC}, 0.1 \%$ SDS and twice for $30 \mathrm{~min}$ at $65^{\circ} \mathrm{C}$ with $0.1 \times$ $\mathrm{SSC}, 0.1 \%$ SDS and then exposed to $\mathrm{x}$-ray film (Curix RPl, AgfaGevaert, Rueil-Malmaison, France) with two intensifying screens (Hi-Plus-Du Pont, Cronex, Du Pont, Wilmington, DE) for 2 to $4 \mathrm{~d}$ at $-80^{\circ} \mathrm{C}$. The $152-\mathrm{bp} 5^{\prime}-E c o$ RI-Rsal fragment was also used as a probe, but labeled by nick-translation (kit, Amersham) (sp act: $4 \times 10^{8} \mathrm{cpm} / \mu \mathrm{g}$ DNA). Hybridizations with each of the two probes were done sequentially. After washing at $45^{\circ} \mathrm{C}$ with 0.4
$\mathrm{M} \mathrm{NaOH}$ for $30 \mathrm{~min}$ and then with $0.1 \times \mathrm{SSC}, 0.1 \% \mathrm{SDS}, 0.2$ $\mathrm{M}$ Tris, $\mathrm{pH} 7.5$, for $30 \mathrm{~min}$ (according to the membrane manufacturer's instructions) to remove the previously hybridized probe, the blot was rehybridized with the second labeled probe.

\section{RESULTS}

Restriction Fragment Length Analysis in Control Population. Twenty-one restriction enzymes were used to analyze human IGF-I DNA. The fragment lengths determined are shown in Table 1. Only three of these enzymes, (EcoRV, HindIII, and PvulI) revealed RFLP (Table 1; Figs. 2 and $3 a$ ) (15). The polymorphic sites for HindIII and PvuII are linked. The incidence of the HindIII and EcoRV RFLP in the control French population are shown in Table 2. When the 152-bp 5' EcoRI-

Table 1. Restriction fragment lengths of human IGF-I gene in control population

\begin{tabular}{|c|c|c|c|c|c|c|}
\hline $\begin{array}{l}\text { Restriction } \\
\text { endonuclease }\end{array}$ & $\begin{array}{c}\text { Controls } \\
(n)\end{array}$ & & Fragment le & lgths (kb) & & \\
\hline ApaI & 24 & 25.0 & 22.0 & 6.0 & & \\
\hline AseI & 14 & 5.4 & 3.8 & 3.4 & 2.1 & \\
\hline AvaII & 51 & 2.0 & 1.7 & 1.3 & 1.2 & \\
\hline BamHI & 20 & 18.0 & 9.2 & 7.0 & 1.0 & \\
\hline$B c / I$ & 18 & 7.4 & 6.0 & 2.5 & 1.8 & \\
\hline$B g / I$ & 19 & 22.0 & 19.0 & 12.0 & & \\
\hline$B g / \mathrm{II}$ & 20 & 11.5 & 8.0 & 3.5 & 2.1 & \\
\hline EcoRI & 16 & 7.7 & 7.0 & 4.5 & 1.4 & \\
\hline HaellI & 15 & 2.0 & 0.6 & 0.3 & & \\
\hline Hinfl & 20 & 0.8 & 0.7 & 0.6 & 0.4 & \\
\hline HphI & 24 & 2.2 & 1.3 & 0.3 & & \\
\hline$K p n \mathrm{I}$ & 21 & 9.6 & & & & \\
\hline MboI & 19 & 1.0 & 0.6 & & & \\
\hline MspI & 19 & 5.5 & 3.5 & 2.0 & 1.5 & 0.7 \\
\hline Rsal & 17 & 0.9 & 0.7 & 0.4 & & \\
\hline SacI & 23 & 6.1 & 3.6 & 2.3 & & \\
\hline TaqI & 25 & 13.4 & 4.7 & 3.3 & 2.4 & \\
\hline Xbal & 20 & 5.0 & 3.5 & 2.3 & & \\
\hline HindIII & 56 & 7.6 & 6.6 & $5.2 / 4.9^{*}$ & 3.0 & \\
\hline$P v u l \mathrm{I}$ & 56 & 7.4 & $5.0 / 4.7^{*}$ & 2.7 & 1.4 & \\
\hline$E c o R V$ & 56 & 20.0 & $13.0 / 11.5^{*}$ & 8.7 & 5.0 & \\
\hline
\end{tabular}

The lengths of the fragments were determined by Southern blot analysis with 21 enzymes, three of which yield polymorphism (*RFLP). a

$\mathrm{kb}$ b

$k b \quad k b$
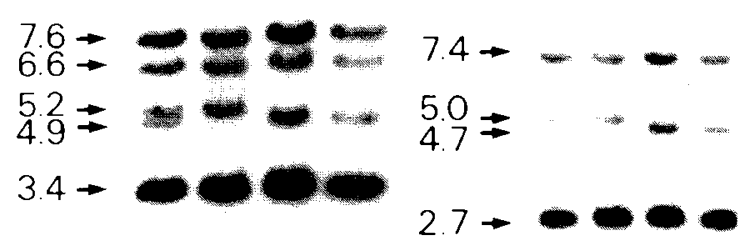

$-5.1$

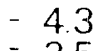

$2.7 \rightarrow$

$-3.5$

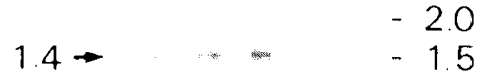

Fig. 2. Southern blot analysis of human DNA from normal subjects. using the 660-bp IGF-I cDNA probe. Genomic DNA digested with $H i n d I I I(a)$ and $P v u$ II $(b)$ revealed polymorphism. The DNA fragment lengths determined using size markers (HindIII-EcoRI-digested phage $\lambda$ DNA) are shown in each panel. The size of the mol wt marker. HindIIIEcoRI-digested phage $\lambda$-DNA, is shown on the right. 
a

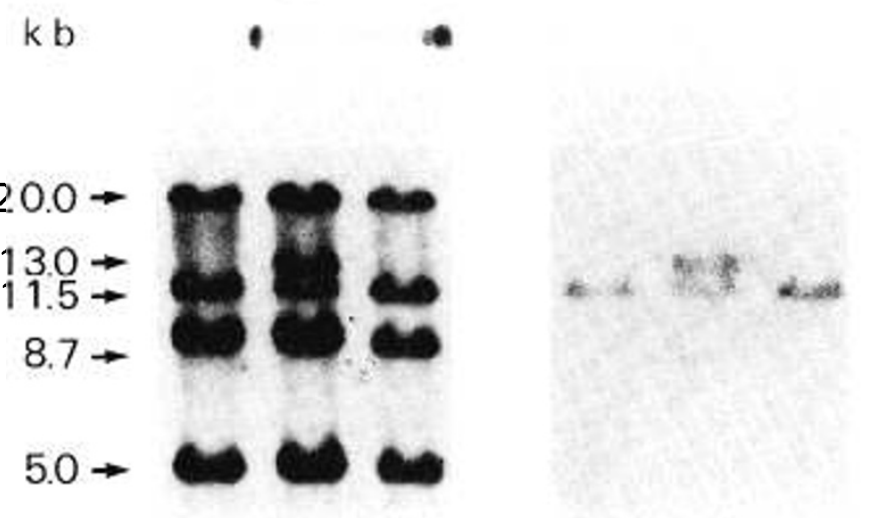

Fig. 3. Southern blot analysis showing the $E c o \mathrm{RV}$ restriction pattern of the IGF-I gene. (a), Hybridization with IGF-I cDNA probe (660 bp: Exons 1, 2, 3, and 5); (b), Same blot hybridized with the 5' EcoRI-RsaI fragment (152 bp: part of Exon 1) of the same IGF-I cDNA insert. The DNA fragment lengths determined using size markers (HindIII-EcoRIdigested phage $\lambda$-DNA) are shown as in Figure 2.

Table 2. Allele frequencies of HindIII and EcoRV polymorphisms at human IGF-I locus in control subjects and in unrelated constitutionally short subjects (CSS)

\begin{tabular}{cccc}
\hline & & Controls & CSS \\
& & $n=56$ & $n=55$ \\
\hline HindIII* & $5.2-\mathrm{kb}$ allele & $17 \%$ & $17 \%$ \\
& $4.9-\mathrm{kb}$ allele & $83 \%$ & $83 \%$ \\
EcoRV & & & \\
& $13-\mathrm{kb}$ allele & $13 \%$ & $4 \% \dagger$ \\
& $11.5-\mathrm{kb}$ allele & $87 \%$ & $96 \%$ \\
\hline
\end{tabular}

*HindIII and PvuII RFLP were linked and yielded the same percentages.

$\dagger$ The difference in incidence of the $13-\mathrm{kb}$ allele between constitutionally short subjects and controls was significant $(p<0.02)\left(\chi^{2}\right.$ test $)$.

$R s a$ I fragment of the IGF-I cDNA (which maps to Exon 1) was used as probe, only the 11.5- and 13-kb polymorphic fragments were observed with the EcoRV-digested DNA (Fig. $3 b$ ).

Human IGF DNA in Subjects with Growth Abnormalities. Constitutionally short subjects. The patterns obtained from Southern blotting using various enzymes, $A v a \mathrm{II}, B a m \mathrm{HI}, B g l \mathrm{I}$, $B g l$ II, EcoRV, HindIII, HinfI, PvuII, and TaqI, were identical to those in controls. Neither IGF-I gene deletions nor abnormalities in the genomes of these subjects were detectable by the method used. EcoRV and HindIII were used as genetic markers to investigate the incidence of RFLP in this group (55 unrelated individuals). The incidence of RFLP for HindIII was similar to that in the control population. That of the polymorphic 13-kb EcoRV was, however, significantly lower (as evaluated by $\chi^{2}$ test, $p<0.02$ ) (Table 2). Analysis of five families using HindIII and $E c o$ RV was uninformative for the IGF-I gene.

Constitutionally tall subjects. The IGF-I gene of 10 such subjects was analyzed using the enzymes HaeIII, BglI, EcoRV, HindIII, PvuII, and TaqI, and no abnormalities were detected in the patterns of the blots.

Pygmies. Five Pygmy samples were analyzed using EcoRV, HindIII, PvuII, and TaqI, yielding results identical to those of controls (Fig. 4).

\section{DISCUSSION}

Analysis of the IGF-I gene in a control population of normal ht enabled us to characterize the restriction profiles and determine fragment lengths for 21 restriction enzymes, as well as to detect RFLP. Of the enzymes tested, only three (EcoRV, HindIII,

\section{$\mathrm{kb}$}

\section{$\mathbf{N} \mathbf{P}$}

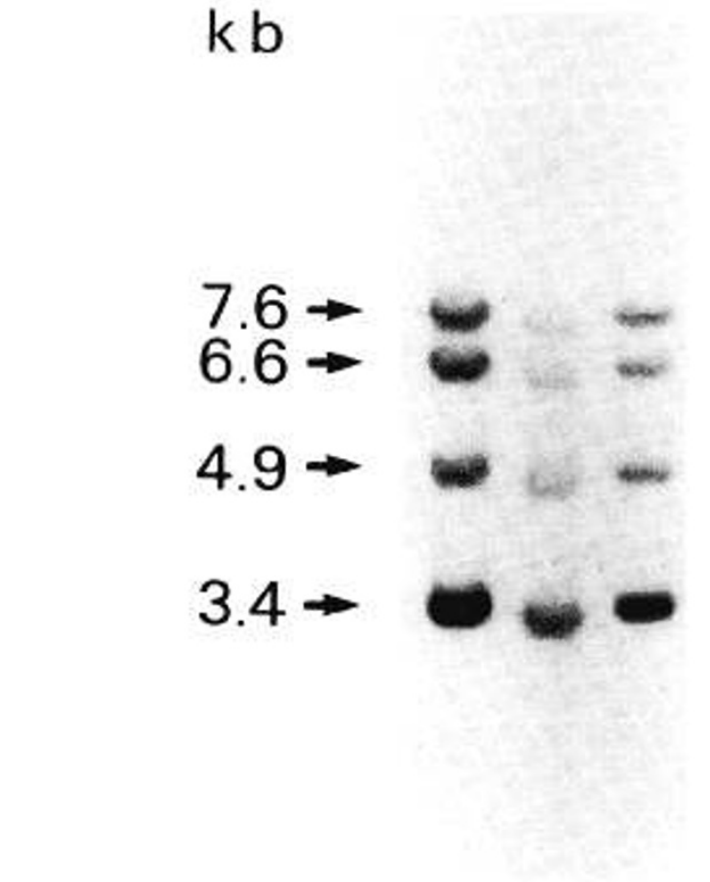

Fig. 4. Southern blot analysis of Pygmy $(P)$ and control $(N)$ DNA digested with HindIII hybridized with the 660-bp IGF-I cDNA probe. The DNA fragment lengths determined using size markers (HindIII$E c 0$ RI-digested phage $\lambda$-DNA) are shown as in Figure 2.

and $P v u \mathrm{II})$ revealed polymorphism (15-18), indicating that there is high conservation of the IGF-I gene. HindIII and PvuII RFLP were found to be linked. Variation of restriction fragment length between the two alleles was $300 \mathrm{bp}$ for the two enzymes, which suggests that an insertion-deletion mechanism would account for the variation (19). The incidence of HindIII and PvuII polymorphism in the French population studied was $17 \%$ for one allele and $83 \%$ for the other. Allele polymorphisms for EcoRV were 13 and $87 \%$. The RFLP with EcoRV and HindIII were not linked. Site polymorphisms for HindIII and PvuII mapped to the region around Exon 5 (18), whereas that for EcoRV was found to map around Exon 1.

With these results for the IGF-I gene in a normal population, it was possible to make comparisons with those for subjects with constitutionally variant stature. In short subjects where the etiology of the condition is probably heterogeneous, differences in IGF-I levels may well reflect differences in GH secretion not detected by pharmacological tests (20-22). However, Zadik et al. (22), studying 24-h integrated GH concentrations, found more than half of the values within the normal range. A possible hypothesis would therefore be that individual variations exist in the expression of the IGF-I gene which accompany normal levels of GH (6). In our studies, Southern blotting revealed no significant deletions or other anomalies in the IGF-I gene of any of these subjects, even in short children with markedly reduced IGF-I levels. The short stature of Pygmies has been attributed to a primary IGF-I deficiency (2), although a recent report suggests a possible defect at the $\mathrm{GH}$ receptor (23). In our study, the restriction profile obtained with leukocyte DNA indicated no detectable anomaly of the IGF-I gene.

With a view to determining whether finer modifications of the IGF-I gene structure may be responsible for the variations in the levels of this factor, we used the RFLP as genetic markers to trace transmission of the different alleles of the IGF-I gene within families. The limited number of RFLP, i.e. three, of which two were linked, and their low incidence (17 and 13\%) gave insuffi- 
cient information for linkage analysis of the five families tested. Nonetheless, the proportion of the 13-kb polymorphic allele obtained with EcoRV proved to be lower (4\%) in the 55 unrelated constitutionally short subjects than in controls (13\%). This means that constitutionally short individuals may comprise a group that is genetically different from normals. More refined techniques (such as genome amplification by the polymerase chain reaction) will need to be applied to establish whether or not anomalies of the IGF-I gene exist in these subjects.

Acknowledgments. The authors thank A. Epelboin and G. Lucotte for providing the Pygmy samples. We thank $\mathrm{L}$. Perin and E. Rousseau for their technical assistance.

\section{REFERENCES}

1. Clemmons DR, Van Wyk JJ 1984 Factors controlling blood concentration of somatomedin C. In: Clinics in Endocrinology and Metabolism, Vol 13. Saunders, Philadelphia, pp 113-143

2. Merimee TJ, Zapf J, Froesch ER 1981 Dwarfism in the pygmy. An isolated deficiency of insulin-like growth factor I. N Engl J Med 305:965-968

3. Gourmelen M. Le Bouc Y, Girard F, Binoux M 1984 Serum levels of insulinlike growth factor (IGF) and IGF binding protein in constitutionally tall children and adolescents. J Clin Endocrinol Metab 59:1197-1204

4. Binoux M, Gourmelen M. Girard F 1986 Serum levels of insulin-like growth factor (IGF) and IGF binding protein in constitutionally short children and adolescents. Acta Endocrinol (Copenh) 113:145-152

5. Rudman D, Chawla RK, Heath WP, Berry CJ, Kutner MH 1986 The hyposomatomedinemic short child. In: Raiti S, Tolman RA (eds) Human Growth Hormone. Plenum Press, New York, pp 135-162

6. Binoux M Gourmelen M 1987 Statural development parallels IGF I levels in subjects of constitutionally variant stature. Acta Endocrinol (Copenh) 114:524-530

7. Sempé M, Pédron G, Roy-Pernot MP 1979 Auxologie, Méthodes et Séquences Theraplix, Paris

8. Gourmelen M, Donnadieu M, Schimpff RM, Lestradet H, Girard F 1972 Effet du chlorydrate d'ornithine sur le taux plasmatique de l'hormone de croissance (hGH). Ann Endocrinol (Paris) 33:526

9. Binoux M, Seurin D, Lassarre C, Gourmelen M 1984 Preferential measurement of insulin-like growth factor (IGF) I-related peptides in serum with the aid of IGF binding proteins (IGF BPs) produced by rat liver in culture. Estimation of serum IGF BP levels. J Clin Endocrinol Metab 59:453-462

10. Binoux M, Lassarre C Gourmelen M 1986 Specific assay for insulin-like growth factor (IGF) Il using the IGF binding proteins extracted from human cerebrospinal fluid. J Clin Endocrinol Metab 63:1151-1155

11. Schimpff RM, Repellin AM, Leduc B, Garnier P, Job JC, Jaeger G 1983 Somatomedin in the Aka pygmies from "Basse-Lobaye." In: Spencer EM (ed) Insulin-like Growth Factors/Somatomedins. Walter de Gruyter, New York, pp 271-275

12. Miller SA, Dykes DD, Polesky HF 1988 A simple salting out procedure for extracting DNA from human nucleated cells. Nucleic Acids Res 16:1215

13. Le Bouc Y, Dreyer D, Jaeger F, Binoux M. Sondermeyer P 1986 Complete characterization of the human IGF-I nucleotide sequence isolated from a newly constructed adult liver cDNA library. FEBS Lett 196:108-112

14. Chomczynski P, Qasbas PK 1984 Alkaline transfer of DNA to plastic membrane. Biochem Biophys Res Commun 122:340-344

15. Schneid H, Noguiez P, Girard F, Binoux M, Le Bouc Y 1988 EcoRV RFLP at the insulin-like growth factor I (IGF I) locus on chromosome 12. Nucleic Acids Res 16:9059

16. Tricoli JV, Rall LB, Scott J, Bell GI, Shows TB 1984 Localization of insulinlike growth factor genes to human chromosomes 11 and 12. Nature 310:784786

17. Höppener JWM, de Pagter-Holthuizen P, Geurts van Kessel AHM, Jansen M. Kittur SD, Antonarakis SE, Lips CJM, Sussenbach JS 1985 The human gene encoding insulin-like growth factor I is located on chromosome 12. Hum Genet 69:157-160

18. Rotwein P, Pollock KM, Didier DK, Krivi GG 1986 Organization and sequence of the human insulin-like growth factor I gene. Alternative RNA processing produces two insulin-like growth factor I precursor peptides. J Biol Chem 261:4828-4832

19. Palmarino R, Mantuano E, Lucarelli P 1988 Genetic variations of insulin-like growth factor I in Italy. Hum Hered 38:186-188

20. Cacciari E, Coccagna G, Cicognani A, Pirazzoli P, Gallassi R, Farneti P, Bernadi F, Zappulla F, Gobbi G, Verucchi P 1978 Growth hormone release during sleep in growth-retarded children with normal response to pharmacological tests. Arch Dis Child 53:487-490

21. Bercu BB, Shulman D, Root AW, Spiliotis BE 1986 Growth hormone $(\mathrm{GH})$ provocative testing frequently does not reflect endogenous $\mathrm{GH}$ secretion. $\mathrm{J}$ Clin Endocrinol Metab 63:709-716

22. Zadik A, Chalew SA, Raiti S, Kowarksi AA 1985 Do short children secrete insufficient growth hormone? Pediatrics 76:355-360

23. Bauman G, Shaw BS, Merimee TJ 1989 Low levels of high affinity growth hormone binding protein in African Pygmies. N Engl J Med 320:1705-1709 